\title{
Anticancer effects of NSC-631570 (Ukrain) in head and neck cancer cells: In vitro analysis of growth, invasion, angiogenesis and gene expression
}

\author{
RUTH HERRMANN ${ }^{1}$, JOSEPH SKAF ${ }^{2}$, JEANETTE ROLLER ${ }^{1}$, CHRISTINE POLEDNIK ${ }^{1}$, \\ ULRIKE HOLZGRABE $^{2}$ and MARIANNE SCHMIDT ${ }^{1}$ \\ ${ }^{1}$ Department of Otorhinolaryngology, University of Würzburg, D-97080 Würzburg; \\ ${ }^{2}$ Institute of Pharmacy and Food Chemistry, University of Würzburg, D-97074 Würzburg, Germany
}

Received September 17, 2018; Accepted September 30, 2019

DOI: 10.3892/or.2019.7416

\begin{abstract}
NSC-631570 (Ukrain) is an aqueous extract of Chelidonium majus, a herbaceous perennial plant, one of two species in the genus Chelidonium, which has been demonstrated to selectively kill tumor cells without affecting non-malignant cells. In the present study, the components of NSC-631570 were examined by combined liquid chromatography/mass spectroscopy (LC-MS) and the effects of NSC-631570 on HNSCC cell lines, as well as primary cells, were analyzed with respect to growth, apoptosis, invasion, angiogenesis and gene expression. LC-MS identified chelerythrine and allocryptopine as the major alkaloids of the extract. Moreover, NSC-631570 suppressed the growth of all tested HNSCC cell lines, including a paclitaxel-resistant and P-glycoprotein (MDR1)-overexpressing cell line. Mucosal keratinocytes were also affected by the extract, while fibroblasts proved to be much more resistant. In contrast to allocryptopine, chelerythrine had toxic effects on HNSCC cell lines at low doses. NSC-631570 significantly induced apoptosis in the $\mathrm{FaDu}$ and $\mathrm{HLaC} 78$ cell lines. As analyzed by a spheroid-based invasion assay, cell migration was significantly suppressed by NSC-631570 in $\mathrm{FaDu}$ cells on gelatine, fibronectin, collagen, laminin and Matrigel $^{\circledR}$. Migration of the highly invasive cell line HLaC78 was also inhibited, albeit to a lesser extent (not significant on
\end{abstract}

Correspondence to: Dr Marianne Schmidt, Department of Otorhinolaryngology, University of Würzburg, 11 Josef-SchneiderStrasse, D-97080 Würzburg, Germany

E-mail: schmidt_m2@klinik.uni-wuerzburg.de

Abbreviations: ECM, extracellular matrix; HNSCC, head and neck squamous cell carcinoma; MDR-1, gene locus multi-drug resistance-1, coding for p-glycoprotein; HUVECs, human umbilical vein endothelial cells; PKC, protein kinase C; VEGF, vascular endothelial growth factor; CYP, cytochrome P450

Key words: NSC-631570, Ukrain, allocryptopine, chelerythrine, Chelidonium majus, carcinoma, head and neck cancer, metastasis, HNSCC, gene expression laminin). Microarray analysis revealed the downregulation of genes encoding key regulators, including EGFR, AKT2, JAK1, STAT3 and B-catenin (CTNNB1), all of which are involved in cell proliferation, migration, angiogenesis, apoptosis as well as the radiation- and chemo-resistance of HNSCC. The strongest upregulation occurred for cytochrome P450 1A1 (CYPIAl) and 1B1 (CYPIB1), involved in the metabolism of xenobiotics. Upregulation of CYPIAl was at least partially caused by chelerythrine and allocryptopine, as shown by RT-qPCR in two HNSCC cell lines. In addition, NSC-631570 showed a high anti-angiogenic action on the tube formation ability of human umbilical vein endothelial cells (HUVECs). In conclusion, this study highlights NSC-631570 as a promising therapeutic approach for HNSCC.

\section{Introduction}

Head and neck squamous cell carcinoma (HNSCC), arising in the oral cavity as well as in the pharyngeal and laryngeal regions of the neck, is the sixth most commonly diagnosed cancer worldwide. In general, complete cure of HNSCC is less than $50 \%$ (1). Despite advanced treatment strategies, the outcome of head and neck cancer has not significantly improved to date (2). For this reason, there is still a demand for new substances suppressing tumor growth and invasion.

Chelidonium majus, the greater celandine, has been historically used to fight cancer and other diseases. It was described in detail in Jonathan Hartwell's compendium (3) 'Plants used against Cancer'. The greater celandine gained overwhelming interest when Ukrain, a drug derived from C. majus, was selected for use in cancer treatment during the 1990s. The drug is, according to the manufacturer, a semi-synthetic derivative of the purified alkaloid chelidonine modified with thiophosphoric acid (Thiotepa). Moreover, it has been proposed to kill tumor cells selectively without damaging primary cells and to exhibit an immune modulatory effect (4-6). There are many studies reporting the treatment of different cancers using Ukrain. During the 1990s, a 'hype' about Ukrain arose and numerous case reports appeared in the no longer published journal 'Drugs Under Experimental and Clinical Research'. Studies reported the benefits of Ukrain such as a prolonged life 
span or even complete remission, without having adverse side effects (7-9). Ukrain was shown to be cytotoxic for a variety of tumor cell lines in vitro (10-13). Furthermore, several groups proved the induction of apoptosis by Ukrain in diverse tumor systems in vitro $(10,14)$.

As it has been shown that chelidonine is not very effective in HNSCC cell lines (15) and there is still a lack of studies of other $C$. majus alkaloids as possible therapeutic agents in HNSCC, the aqueous extract NSC-631570 was chosen to be tested in vitro for its action in HNSCC.

Combined liquid chromatography and mass spectroscopy of NSC-631570 was applied. The effects of NSC-631570 and its major alkaloid chelerythrine on drug-sensitive and drug-resistant HNSCC cell lines and on primary mucosal keratinocytes and fibroblasts were investigated in the present study. Apoptosis as well as the influence of the extract on gene expression and on the motility of HNSCC cells in a 3-dimensional, spheroid-based invasion assay were analyzed. The results are discussed critically with respect to previously published research.

\section{Materials and methods}

Reagents. NSC-631570 was kindly provided by Dr Wassil Novicky (Vienna, Austria), who is the inventor of Ukrain. Reference substances chelidonine, allocryptopine, chelerythrine and sanguinarine were purchased from Sigma-Aldrich; Merck KGaA.

Liquid chromatography-mass spectroscopy of NSC-631570. LC-MS analysis was performed using a Shimadzu LC-MS-2020 mass spectrometer (Shimadzu Deutschland $\mathrm{GmbH}$ ) containing a DGU-20A3R degassing unit, a LC20AB liquid chromatograph and SPD-20A UV/Vis detector. A Synergi 4 U fusion-RP column (150x4.6 mm; Phenomonex) was used as a stationary phase, and a gradient of $\mathrm{MeOH} /$ water was applied as a mobile phase: Solvent A: water with $0.1 \%$ formic acid, solvent B: $\mathrm{MeOH}$ with $0.1 \%$ formic acid. Solvent A ranged from 0 to $100 \%$ in $8 \mathrm{~min}$, and then remained at $100 \%$ for $5 \mathrm{~min}$, before reducing from 100 to $5 \%$ in $1 \mathrm{~min}$, and then being held $5 \%$ for $4 \mathrm{~min}$, The method was performed with a flow rate of $1.0 \mathrm{ml} / \mathrm{min}$, and $\mathrm{UV}$ detection was measured at $245 \mathrm{~nm}$. Allocryptopine, chelerythrine, sanguinarine and chelidonine were used as reference substances.

Cell lines and cell culture. Squamous cell carcinoma cell lines, originating from laryngeal or hypopharyngeal tumors were used for the study, comprising the major proportion of cases treated at the ENT, Wuerzburg University Hospital. The cell line FaDu (LG standards) originating from a hypopharyngeal carcinoma was grown in RPMI-1640 medium (Seromed), supplemented with $10 \%$ foetal bovine serum (FBS). HLaC78 and HLaC79 cell lines derived from larynx carcinoma (16) were maintained in RPMI-1640 medium. HLaC79-Tax was obtained by isolation and the selective cultivation of a paclitaxel-resistant HLaC79 clone. It was grown as the original cell line supplemented with $10 \mathrm{nM}$ (HLaC79-Tax) paclitaxel. As primary cells, human mucosal fibroblasts and keratinocytes were used. Fibroblast and keratinocyte cultures used, were thawed from frozen samples, generated from a tonsil surgery specimen in 2007. Fibroblast cultures were established by explant cultures in DMEM/10\% FBS. The isolation of keratinocytes was performed as previously described (17). Keratinocytes were maintained in Keratinocyte Medium 2 (PromoCell). Patient informed written consent was obtained prior to the study. The present study was approved by the Institutional Ethics Committee on Human Research of The Julius Maximilian University of Wuerzburg (study approval no. 16/06).

Cell viability and proliferation assay. Cells were seeded at 5,000 cells/well in 96-well plates. The cells were then treated with increasing concentrations of NSC-631570, chelerythrine or allocryptopine for $48 \mathrm{~h}$. Cell proliferation was measured $48 \mathrm{~h}$ later by administration of MTT at a concentration of $1 \mathrm{mg} / \mathrm{ml}$. After a 4-h incubation, MTT-staining solution was replaced by isopropanol and the cells were incubated at $37^{\circ} \mathrm{C}$ for $45 \mathrm{~min}$. The color change of yellow MTT to a blue formazan dye was measured with an ELISA reader at a wavelength of $570 \mathrm{~nm}$. Relative toxicity was calculated as the surviving cell $\%$ by setting solvent-treated control cells to $100 \%$.

Apoptosis. FACS analysis was performed using the BD Pharmingen Annexin V-APC kit (BD Biosciences) according to the kit manual. In brief, $\mathrm{HLaC} 78$ and $\mathrm{FaDu}$ cells were treated with $\mathrm{EC}_{50}$ concentrations of NSC-631570 or chelerythrine, respectively for $24 \mathrm{~h}$, harvested and washed twice with cold PBS. The shortened incubation time was chosen in order to enrich early apoptotic stages within the cell populations (18). Cells were then resuspended in $1 \mathrm{X}$ binding buffer $(0.1 \mathrm{M}$ HEPES, pH 7.4, $1.4 \mathrm{M} \mathrm{NaCl}, 25 \mathrm{mM} \mathrm{CaCl}_{2}$ ) at a concentration of $1 \times 10^{6}$ cells $/ \mathrm{ml}$. To $100 \mu \mathrm{l}$ of this cell suspension, $5 \mu \mathrm{l}$ Annexin V-APC and $5 \mu 1$ 7-AAD (included in the kit) were added, the cells were vortexed and incubated for $15 \mathrm{~min}$ in the dark. An amount of $400 \mu \mathrm{l}$ of $1 \mathrm{X}$ binding buffer was added. Within $1 \mathrm{~h}$, FACS analysis was performed at an excitation wavelength of $650 \mathrm{~nm}$.

In vitro invasion assay. Tumor spheroids were established by dispending 5,000 cells/well of HLaC78 cells on ultra-low-attachment (ULA) 96-well round-bottomed plates (Corning, Inc.). For the migration assay, spheroids of HLaC78 were transferred manually to different extracellular matrix substrates. For this reason, the surface of flat-bottomed 96-well plates was coated with $0.1 \%$ gelatine, $5 \mu \mathrm{g} / \mathrm{ml}$ fibronectin, $50 \mu \mathrm{g} / \mathrm{ml}$ laminin, $50 \mu \mathrm{g} / \mathrm{ml}$ collagen I (all purchased at Sigma Aldrich; Merck KGaA) or $125 \mu \mathrm{g} / \mathrm{ml}$ Matrigel ${ }^{\circledR}$ (Becton Dickinson) for $2 \mathrm{~h}$ at room temperature. Wells were washed twice with PBS and blocked with $1 \%$ bovine serum albumin in PBS for $1 \mathrm{~h}$; 72-h old spheroids were then manually transferred to the coated wells. Spheroids were incubated with or without NSC- 631570 or chelerythrine. Migration was analyzed by photographing spheroids after 1 and $24 \mathrm{~h}$ with a Leica DMI 4000 inverted fluorescence microscope (Leica Microsystems) at 5-fold magnification. Incubation time was chosen due to the fact, that the cell line HLaC78 needs approximately $24 \mathrm{~h}$ to invade completely without inhibiting substances (personal observation). Quantification of migrated areas was performed with ImageJ software (version 1.52a; National Institutes of Health, NIH, Bethesda, MD, USA). 
RNA extraction and RNA quality control. RNA of HNSCC cell cultures was isolated with the RNeasy kit (Qiagen) according to the manufacturer's instructions. Purity and concentration were determined photometrically. In expression arrays, RNA quality was determined with the RNA 6000 Nano kit and a Bioanalyzer 2100 instrument (Agilent). RNA integrity numbers (RINs) of our samples ranged between 9.4 and 9.7.

Microarray analysis. For microarray hybridization, $100 \mathrm{ng}$ total RNA was amplified and labelled using the IVT Express kit and hybridized to GeneChip PrimeView Human Gene Expression arrays (both from Affymetrix; Thermo Fisher Scientific, Inc.) according to the manufacturer's instructions. Raw microarray data were background corrected, normalized and summarized to probe set expression values using the Robust Microarray Average (RMA) algorithm $(19,20)$. Data pre-processing and calculation of fold-changes between treated and untreated expression values was performed with the Affymetrix Transcriptome analysis Console 4.0.1 (Affymetrix; Thermo Fisher Scientific, Inc.). Microarray data were deposited in MIAME-compliant form at Gene Expression Omnibus (http://www.ncbi.nlm.nih.gov/geo) with the identifier GSE115874.

TaqMan real-time PCR. In order to confirm the strong increase in CYPIAl expression caused by NSC-631570 in FADU cells and other HNSCC cell lines, FaDu and HLaC78 cell lines were treated for $48 \mathrm{~h}$ with either chelerythrine, allocryptopine or NSC-631570 at their $\mathrm{EC}_{50}$ concentrations. RNA was isolated (see above section) and real-time TaqMan PCR (Applied Biosystems; Thermo Fisher Scientific, Inc.) was performed in triplicates on a real-time PCR cycler (Applied Biosystems; Thermo Fisher Scientific, Inc.) using the TaqMan gene expression assay for CYPIA1. Relative quantification was calculated according to the $2^{-\Delta \Delta \mathrm{Cq}}$ method (21). Expression values were normalized to the expression of GAPDH as an endogenous control, stably expressed in HNSCC cell lines.

Tube formation assay. Using tube formation assays, the ability of endothelial cells to form three-dimensional capillary-like structures was analyzed. Ibidi angiogenesis slides (15-well, Ibidi $\mathrm{GmbH}$ ) were coated with growth factor reduced basement membrane extract (BME; Trevigen). BME gels were overlaid with $1 \times 10^{4}$ human umbilical vein endothelial cells (HUVECs) in growth medium, with and without the addition of NSC-631570 or chelerythrine, respectively. Cells were incubated for $6 \mathrm{~h}$ and images were captured. Analysis of the images was performed by Wimasis. For quantification, four parameters were analyzed: tube length, number of branching points, covered area and number of loops.

Statistical analysis. All statistical analyses and graphs were performed with Graph Pad Prism 6 (GraphPad Software, La Jolla, CA, USA). Data are presented as the mean of three independent experiments or 8 measured spheroids \pm standard deviation. As statistical tests unpaired t-test (angiogenesis, migration measurements) or ANOVA Dunnett's multiple comparison test (RT-qPCR) were used. Differences were considered to be significant as indicated in the figures and legends: ${ }^{* * * *} \mathrm{P}<0.0001,{ }^{* * *} \mathrm{P}<0.001,{ }^{* * *} \mathrm{P}<0.01,{ }^{*} \mathrm{P}<0.05$.

\section{Results}

LC-MS analysis. LC-MS analysis of the NSC-631570 extract displayed four major peaks at $6.5,6.6,7.5$ and $7.7 \mathrm{~min}$ in the UV chromatogram at $254 \mathrm{~nm}$ (Fig. 1A) with the percentage area of 10.9, 13.8, 21.7 and 43.9\%, respectively (Fig. 1B). Corresponding molecular masses are shown in Fig. 1C.

LC-MS of the reference substances revealed molecular masses of 369.05 for allocryptopine, 347.01 for chelerythrine, 331.05 for sanguinarine and 352.95 for chelidonine. According to the present analysis, the most abundant constituents of NSC-631570 are chelerythrine (43.86\%) and allocryptopine (24.72\%). Their effective concentrations in an extract solution of $10 \mu \mathrm{g} / \mathrm{ml}$ were calculated to be $2.47 \mu \mathrm{g} / \mathrm{ml}$ for allocryptopine and $4.39 \mu \mathrm{g} / \mathrm{ml}$ for chelerythrine.

Cytotoxicity. The cell lines FaDu, HLaC78, HLaC79, HLaC79-Tax, primary mucosal keratinocytes (MKs) and fibroblasts were incubated with increasing concentrations of NSC-631570 $(10,25,50,100 \mu \mathrm{g} / \mathrm{ml})$ for $48 \mathrm{~h}$. The MTT assay was used to measure cell viability and cytotoxicity (Fig. 2). For the calculation of inhibition rates, at least three independent experiments were carried out.

NSC-631570 treatment showed clear dose-response curves with calculated $\mathrm{EC}_{50}$ concentrations varying around an average concentration of $10 \mu \mathrm{g} / \mathrm{ml}$ (FaDu 10.99, HLaC78 9.34, HLaC79 12.4, HLaC79-Tax 9.62, MKs 10.65, fibroblasts $\sim 10.47 \mu \mathrm{g} / \mathrm{ml}$ ).

P-glycoprotein-overexpressing HLaC79-Tax cells were similarly affected by NSC-631570 as their original paclitaxel-sensitive cell line HLaC79. MKs were also sensitive to NSC-631570, while fibroblasts proved to be much more resistant, even at high concentrations (Fig. 2).

Chelerythrine exerted strong cytotoxicity on HNSCC cell lines $\mathrm{FaDu}$ and $\mathrm{HLaC} 78$ with an $\mathrm{EC}_{50}$ dose of approximately $3 \mu \mathrm{M}$ (Fig. 3). Allocryptopine, however, revealed only weak cytotoxic effects on HNSCC cell lines, even at non-physiological doses up to $500 \mu \mathrm{M}$ (Fig. 3).

Apoptosis. Apoptosis of NSC-631570 (NSC) or chelerythrine treated (CE) and untreated (Co) FaDu and $\mathrm{HLaC} 78$ cells was determined after $24 \mathrm{~h}$ incubation by FACS analysis. Cell lines were incubated with the calculated $\mathrm{EC}_{50}$ doses of each drug. Flow cytometry analysis using the APC Annexin V kit showed an apoptosis-promoting effect for NSC-631570 in both cell lines. With the $\mathrm{EC}_{50}$ dose of $10 \mu \mathrm{g} / \mathrm{ml}, \mathrm{NSC}-631570$ revealed a discrete apoptotic cell fraction of $13.1 \%$ in $\mathrm{FaDu}$ and $13.5 \%$ in HLaC78 cells, respectively (Fig. 4).

Chelerythrin had a stronger effect with regard to triggering apoptosis, especially in $\mathrm{HLaC} 78$ cells. The corresponding $\mathrm{EC}_{50}$ concentrations achieved 15.3\% (FaDu) and 28.3\% (HLaC78) of cells at the pre-apoptotic stages (Fig. 4).

Cell motility on extracellular matrix (ECM) proteins. Spheroid-based experiments were used to investigate the influence of NSC-631570 on invasion on different ECM substrates.

Spheroids of $\mathrm{FaDu}$ and $\mathrm{HLaC} 78$ cells were grown in ultra-low-attachment-plate wells. After $72 \mathrm{~h}$, they were pipetted into wells, coated with gelatine, fibronectin, laminin, collagen I and Matrigel and incubated with (Uk) or without (Co) NSC-631570 or chelerythrine (CE) for $18 \mathrm{~h}$. Cell migration was 
A

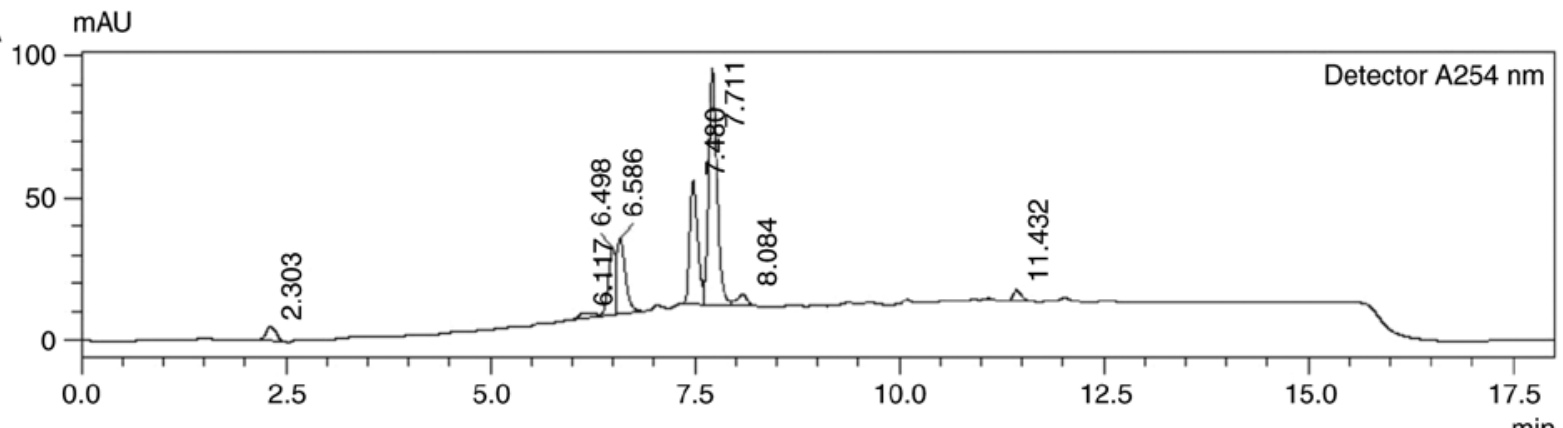

B Detector A $254 \mathrm{~nm}$

\begin{tabular}{|r|r|r|r|r|}
\hline \multicolumn{1}{|c|}{ Peak\# } & \multicolumn{1}{|c|}{ Ret. Time } & \multicolumn{1}{c|}{ Area } & \multicolumn{1}{c|}{ Height } & \multicolumn{1}{c|}{ Area\% } \\
\hline 1 & 2.303 & 42032 & 4769 & 3.164 \\
\hline 2 & 6.117 & 22582 & 1516 & 1.700 \\
\hline 3 & 6.498 & 145082 & 23555 & 10.922 \\
\hline 4 & 6.586 & 183251 & 26328 & 13.796 \\
\hline 5 & 7.480 & 287933 & 43348 & 21.676 \\
\hline 6 & 7.711 & 582649 & 83150 & 43.864 \\
\hline 7 & 8.084 & 36126 & 4250 & 2.720 \\
\hline 8 & 11.432 & 28663 & 3993 & 2.158 \\
\hline Total & & 1328318 & 190908 & 100.000 \\
\hline
\end{tabular}

\begin{tabular}{|c|c|c|c|}
\hline Peak min & $\%$ Area & MW g/mol & Proposed substance \\
\hline 6498 & 10922 & 369.05 & Allocryptopine \\
\hline 6586 & 13796 & 369.05 & Allocryptopine \\
\hline 7480 & 21676 & 331.05 & Sanguinarine \\
\hline 7711 & 43864 & 347.01 & Chelerythrine \\
\hline
\end{tabular}

Figure 1. (A) UV-chromatogram of NSC-631570. y-axis, mAU (milli-absorbance units); $x$-axis, retention time in min. (B) Table of eluted peaks of NSC-631570. (C) Major peaks of LC-MS analysis of NSC-631570 with corresponding molecular masses.
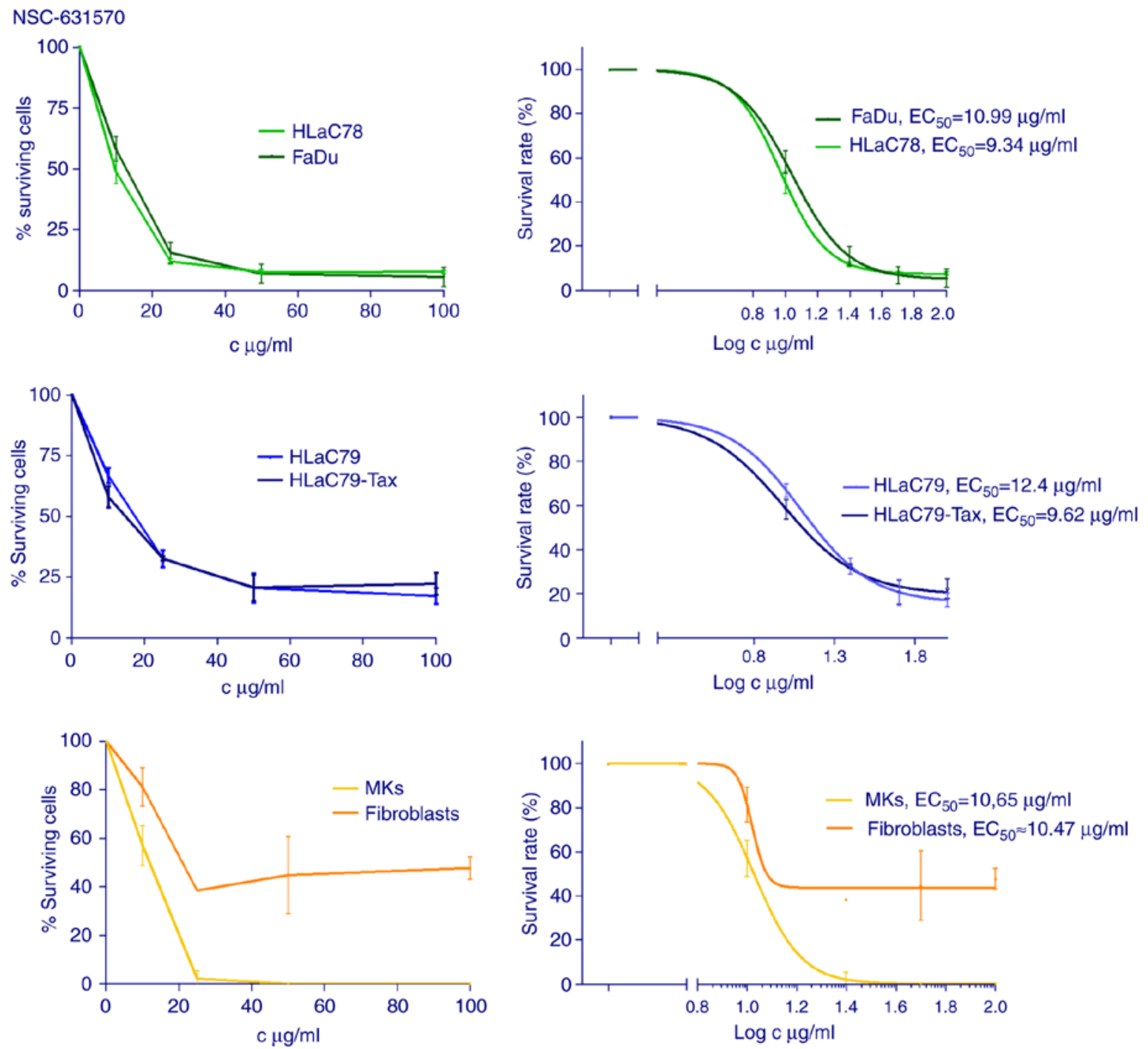

Figure 2. Cytotoxic effect of NSC-631570 at increasing concentrations on HNSCC cell lines HLaC78, FaDu, HLaC79, HLaC79-Tax and primary mucosal keratinocytes (MKs) and fibroblasts as assessed with the MTT assay. Data are presented as the mean of three independent experiments \pm standard deviation. Left panels, dose-response curves; right panels, statistical curve fitting/calculation of $\mathrm{EC}_{50}$ (response vs. agonist, variable slope). 


\begin{tabular}{|c|l|c|c|c|c|}
\hline FaDu & HLaC78 & MKs & FBs & HLaC79 & HLaC79-Tax \\
\hline 3.545 & 2.980 & 2.249 & 1.985 & 4.754 & 4.574 \\
\hline
\end{tabular}
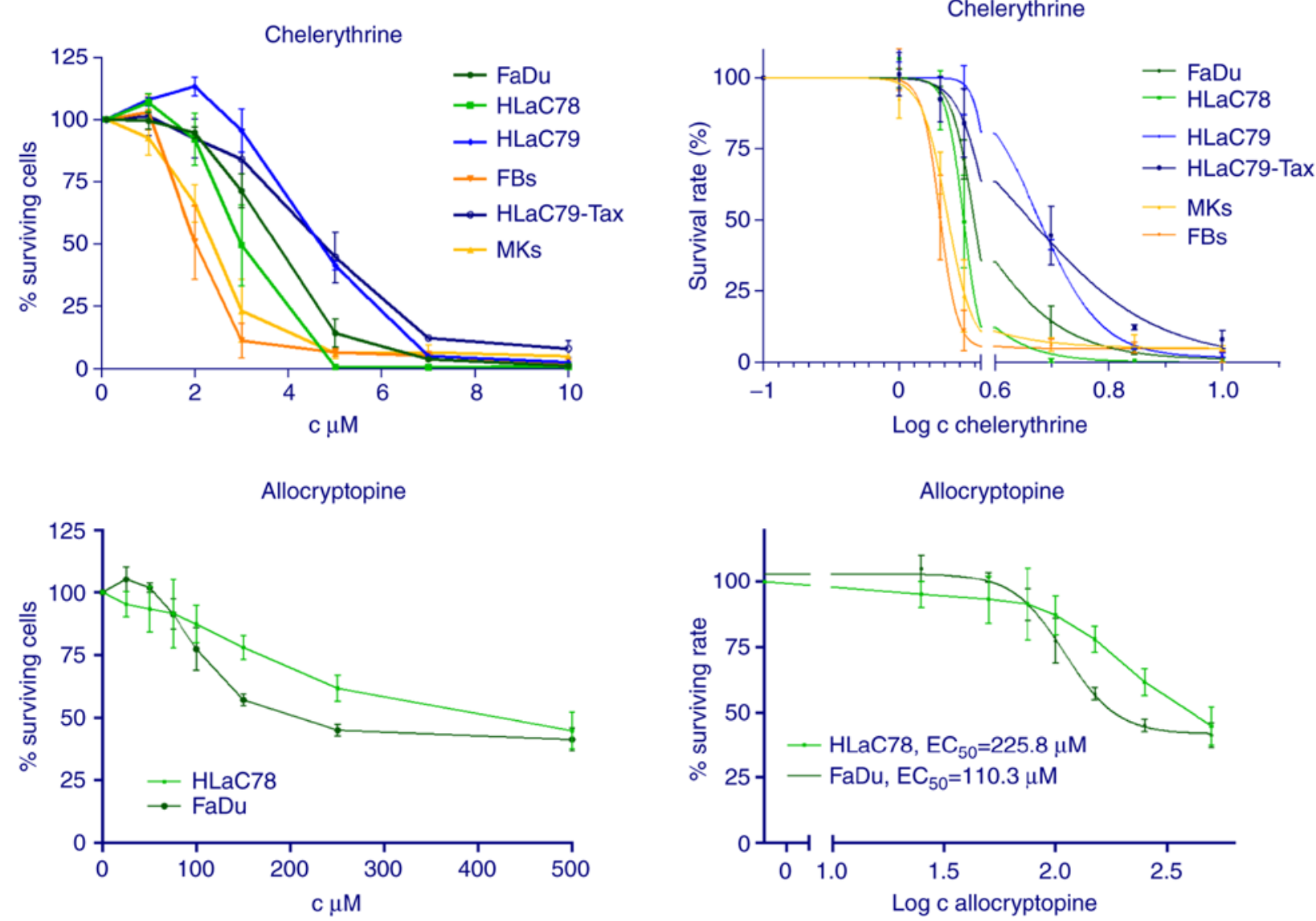

Figure 3. Cytotoxic effect of chelerythrine on HNSCC cell lines and primary cells, as well as allocryptopine on HNSCC cell lines FaDu and HLaC78 at increasing concentrations, as assessed using the MTT assay. Left panels, dose-response curves; right panels, statistical curve fitting/calculation of $\mathrm{EC}_{50}$ (response vs. agonist, variable slope). Calculated $\mathrm{EC}_{50}$ values are indicated in the corresponding graphs. Data are presented as the mean of three independent experiments \pm standard deviation. MKS, primary mucosal keratinocytes; FBs, fibroblasts.

quantified by photographing native and outgrown spheroids at $\mathrm{t}=0$ and $\mathrm{t}=18$. Outgrown areas were measured with Image $\mathrm{J}$ software (area calculation). For each condition, eight spheroids were measured. Calculation of cell motility was achieved by setting the area at $\mathrm{t}=0$ at $100 \%$. Results are displayed in Fig. 5.

The comparison of migrated areas revealed a strong suppression of motility in FaDu cells induced by NSC-631570 on all tested ECM surfaces. Invasion of the highly invasive HLaC78 cell line was also significantly suppressed with the exception of laminin (Fig. 5). Chelerythrine showed no anti-invasive influence in the spheroid-based migration assay (Fig. 5).

Gene expression. To generate a gene expression profile of the NSC-631570-treated cells, microarray analysis was performed using FaDu cells which were treated for $48 \mathrm{~h}$ with the $\mathrm{EC}_{50}$ of NSC-631570 $(10 \mu \mathrm{g} / \mathrm{ml})$. Of a total number of 49,372 genes tested, $223(0.45 \%)$ were upregulated and $696(1.41 \%)$ were downregulated by NSC-631570. The top 50 upregulated and downregulated genes are summarized in Table IA and B. Complete array results have been deposited at Gene Expression Omnibus (http://www.ncbi.nlm.nih.gov/geo) with the identifier GSE115874. Pathway analysis revealed major expression changes affecting apoptosis, cell cycle, integrin-mediated cell adhesion, RNA processing and translation factors, as summarized in Table II.

Microarray data validation by TaqMan RT-PCR. Real-time PCR was performed for NSC-631570-treated cell lines FaDu and HLaC78 to verify array results and to analyze whether differential gene expression is a cell-type independent process. For RT-qPCR, TaqMan probes for CYPIAI and CyplBI were chosen, as these genes were the most upregulated genes and with respect to a previously published study, downregulation of these genes was observed following treatment with a Chelidonium majus extract (22). $\mathrm{FaDu}$ and $\mathrm{HLaC} 78$ cells were treated with (NSC) or without (Co) NSC-631570 or $\mathrm{EC}_{50}$ concentrations of chelerythrine (CE) or allocryptopine (AC) respectively, for $48 \mathrm{~h}$.

CYP1A1 and CYP1B1 expression was upregulated in both cell lines in response to treatment with NSC-631570, verifying array data and indicating a specific effect of the Chelidonium majus extract, which was not restricted to one cell line (Fig. 6). Chelerythrine and allocryptopine at least contributed to CYPIAl upregulation in both cell lines as compared to the control (Co). For CYPIB1, upregulation was confirmed 

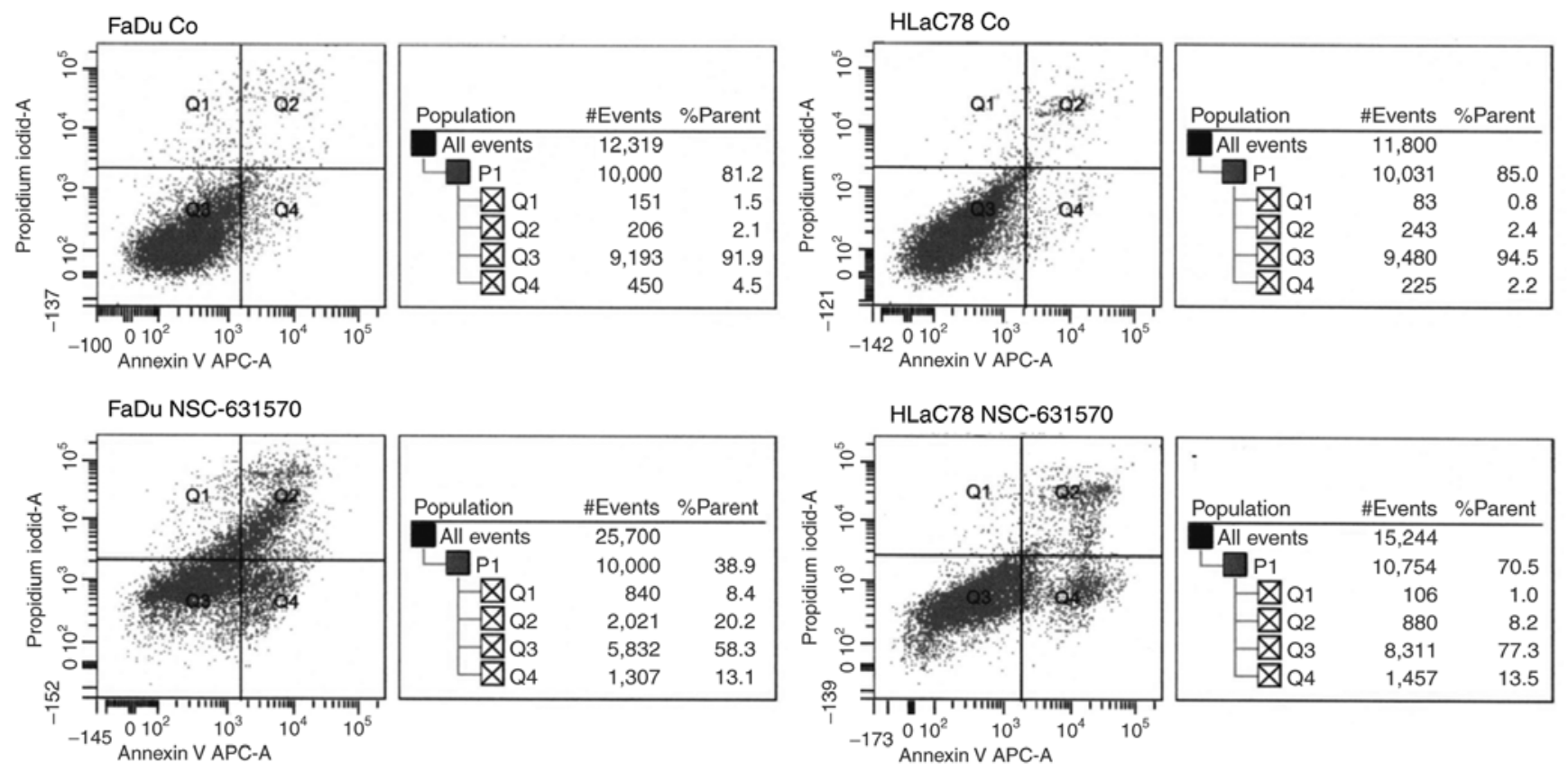

FaDu Co
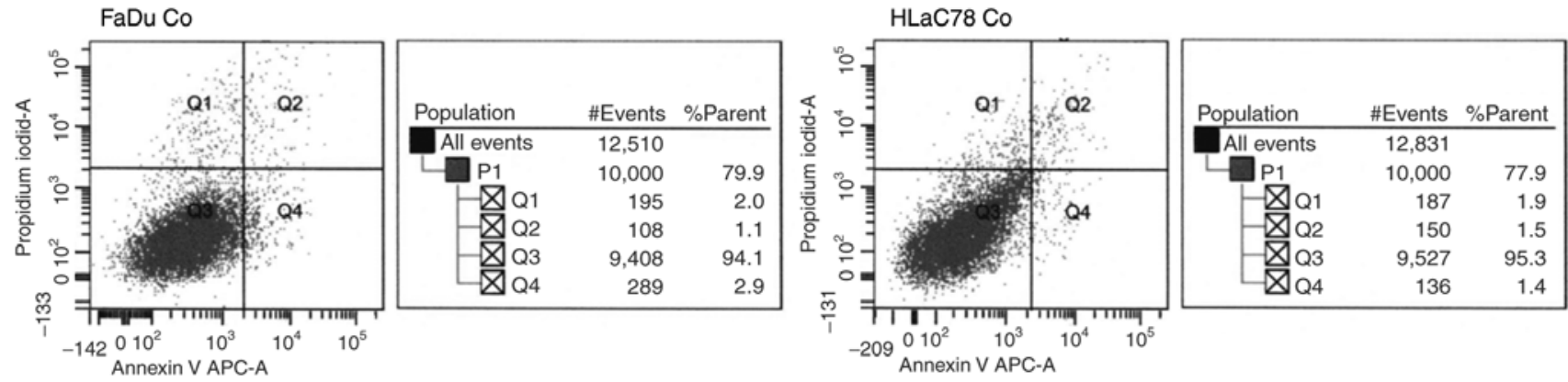

FaDu CE
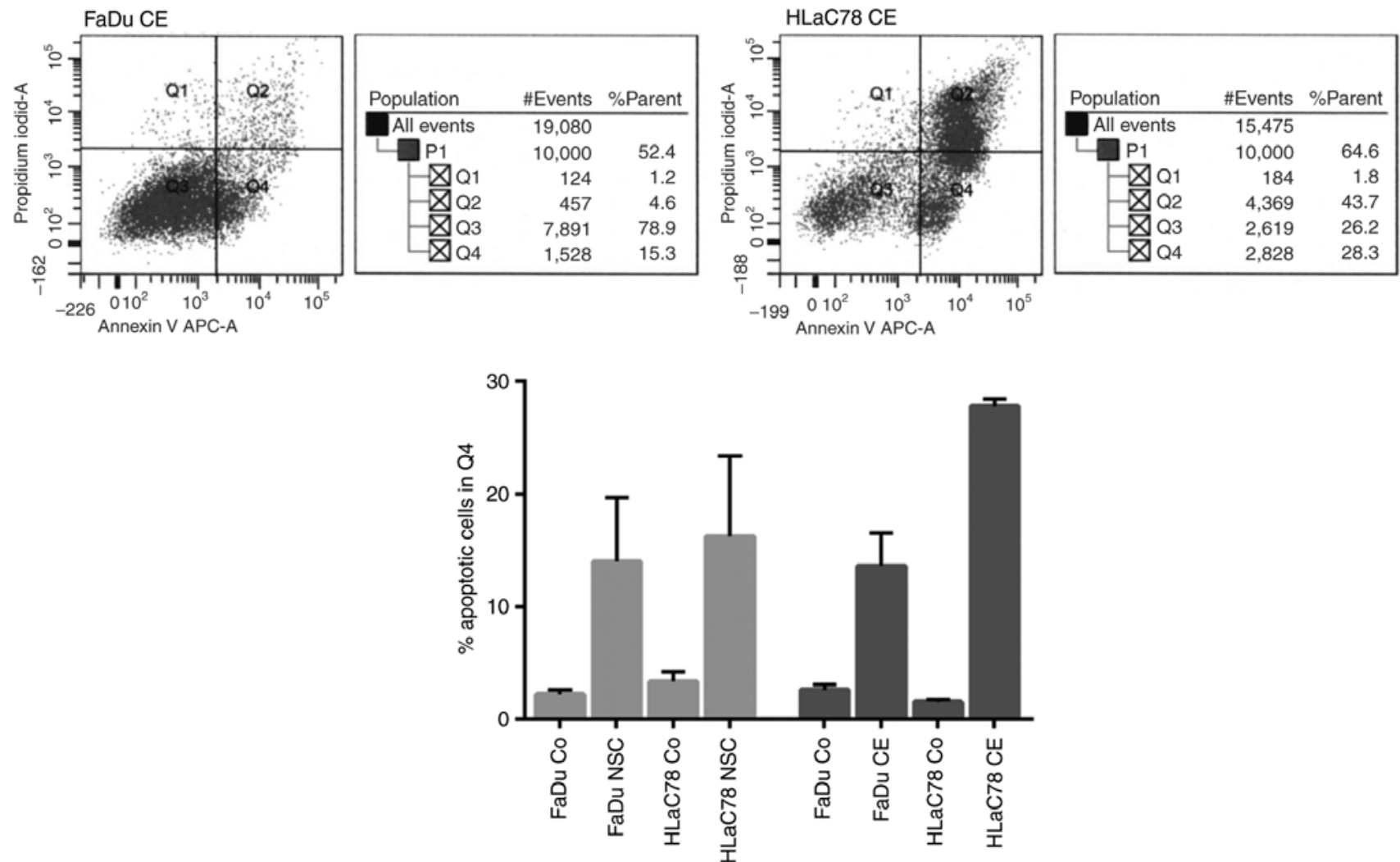

Figure 4. FACS analysis of early apoptotic events using the APC Annexin V kit for NSC-631570 (NSC) or chelerythrine (CE) treated FaDu and HLaC78 cells. FaDu and HLaC78 cells were incubated for $24 \mathrm{~h}$ with the $\mathrm{EC}_{50}$ of NSC-631570 $(10 \mu \mathrm{g} / \mathrm{ml})$ or chelerythrine $\mathrm{EC}_{50}(3 \mu \mathrm{M})$. Results are summarized in the diagram below. Co, untreated control cells. 

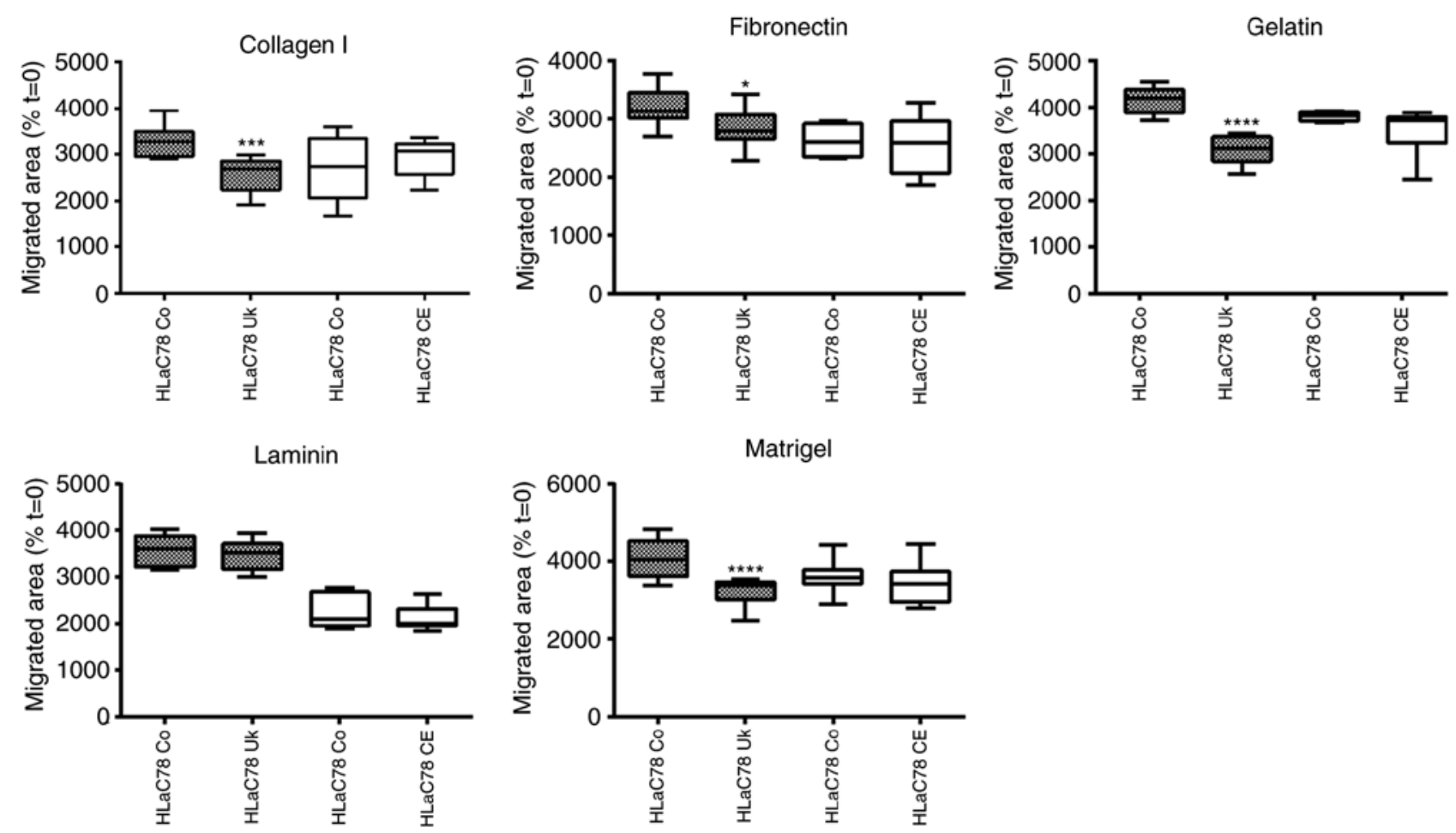

Figure 5. Migration of NSC-631570 (Uk) or chelerythrine (CE)-treated and control (Co) HLaC78 cells on different ECM protein-coated surfaces. Spheroids were treated with respective $\mathrm{EC}_{50}$ concentrations for $24 \mathrm{~h}$. Migration of the cells was determined setting spheroid area of $\mathrm{t}=0$ at $100 \%$ percentage of migration of NSC-631570/chelerythrine-treated HLaC78 cells. Data are presented as the mean of eight spheroids \pm standard deviation. ${ }^{* * * *} \mathrm{P}<0.0001,{ }^{* * * *} \mathrm{P}<0.001,{ }^{*} \mathrm{P}<0.05$ statistically significant values (unpaired t-test) compared to the control.

in both cell lines following treatment with NSC-631570. Treatment with chelerythrine or allocryptopine showed no significant difference in expression changes compared to the untreated control.

Angiogenesis. NSC-631570 was tested for anti-angiogenic properties with the tube formation assay. Tube formation of endothelial cells, naturally occurring on reconstituted basement membrane, was obviously inhibited by the Chelidonium majus extract NSC-631570 (Fig. 7, upper panels). The quantification of inhibition showed significant decreases in all parameters tested (Fig. 7). There was no significant inhibition of any tube formation parameter by chelerythrine (CE) (Fig. 7, lower panels).

\section{Discussion}

In the present study, the Chelidonium majus extract NSC-631570 was examined for its effect on HNSCC cell lines in vitro. Particularly, the influence of the drug with respect to cell growth, apoptosis, migration and angiogenesis on tumor cells as well as its cytotoxicity against primary cells was investigated.

LC-MS analysis revealed chelerythrine and allocryptopine to be the most abundant alkaloids of the Chelidonium majus extract. Composition of the extract was found to be essentially comparable to the LC/MS analysis data of Ukrain published by Jesionek et al in 2016 (23).

NSC-631570 was demonstrated to exhibit strong cytotoxic activity on HNSCC tumor cells, originating from laryngeal or hypopharyngeal subsites, even on those overexpressing p-glycoprotein. Results may differ for head and neck cell lines, derived from other locations. Primary cells were also affected by NSC-631570; however, sensitivity differed between generally sensitive epithelial keratinocytes and mucosal fibroblasts. Fibroblasts were much more resistant against NSC-631570 compared to the HNSCC cell lines tested in this study. Therefore, this study cannot support the advertised selective toxicity of Ukrain on cancer cells without restriction. In 2013, a study was published, which analyzed the uptake and intracellular effects of celandine alkaloids in normal and malignant cells (24). Obviously, the toxicity of alkaloid mixtures depends on the differential uptake into the different cell types as well as various targets within the cells (e.g. post-translational modified tubulin isotypes), also differing between cell types. Therefore, the exact effect of an alkaloid mixture in differential cell systems seems to be hardly predictable. Chelerythrine showed a comparable toxicity profile on tumor cell lines, but also a harsher effect on primary cells, also on fibroblasts. This is in agreement with the study of Malíková et al (25), who also observed increased sensitivity of primary cells against chelerythrine. Chelerythrine is a known protein kinase $\mathrm{C}$ (PKC) inhibitor and in general PKC inhibitors such as staurosporin and others have failed to be effective in cancer therapy, although anticancer activity was exhibited in several in vitro systems (reviewed in ref. 26). Recently, however, new mechanisms of action beyond PKC inhibition have been published for chelerythrine, concerning the influence on gene expression in cancer cells $(27,28)$. These results, together with the observation, that chelerythrine is able to delay the growth 
Table I. The top 50 upregulated and downregulated genes in FaDu cells triggered by treatment with $10 \mu \mathrm{g} / \mathrm{ml} \mathrm{NSC-631570} \mathrm{for}$ $48 \mathrm{~h}$.

A, Upregulated genes

\begin{tabular}{|c|c|c|}
\hline $\mathrm{FC}$ & Gene symbol & Description \\
\hline 23.44 & CYP1Al & Cytochrome P450, family 1, subfamily A, polypeptide 1 \\
\hline 8.00 & $C Y P 1 B 1$ & Cytochrome P450, family 1, subfamily B, polypeptide 1 \\
\hline 5.61 & $X A F 1$ & XIAP associated factor 1 \\
\hline 5.35 & $M X 2$ & MX dynamin-like GTPase 2 \\
\hline 5.01 & $I S G 20$ & Interferon stimulated exonuclease gene $20 \mathrm{kDa}$ \\
\hline 4.61 & $O T U B 2$ & OTU deubiquitinase, ubiquitin aldehyde binding 2 \\
\hline 4.37 & OAS2 & 2'-5'-Oligoadenylate synthetase 2 \\
\hline 4.26 & NFATC4 & Nuclear factor of activated T-cells, calcineurin-dependent 4 \\
\hline 4.12 & OAS1 & 2'-5'-Oligoadenylate synthetase 1 \\
\hline 4.07 & SPOCK1 & Sparc/osteonectin \\
\hline 3.99 & IRF9 & Interferon regulatory factor 9 \\
\hline 3.94 & $A L D H 3 A 1$ & Aldehyde dehydrogenase 3 family, member A1 \\
\hline 3.80 & SERPINB2 & Serpin peptidase inhibitor, clade B (ovalbumin), member 2 \\
\hline 3.78 & IFI44L & Interferon-induced protein 44 -like \\
\hline 3.51 & $R H C G$ & Rh family, C glycoprotein \\
\hline 3.44 & $N A V 3$ & neuron navigator 3 \\
\hline 3.43 & COLAA6 & Collagen. type IV, $\alpha 6$ \\
\hline 3.39 & $F A 2 H$ & Fatty acid 2-hydroxylase \\
\hline 3.31 & $M D K$ & Midkine (neurite growth-promoting factor 2) \\
\hline 3.29 & DHX58 & DEXH (Asp-Glu-X-His) box polypeptide 58 \\
\hline 3.28 & PCDHB2 & Protocadherin $\beta 2$ \\
\hline 3.26 & $M Y E O V$ & Myeloma overexpressed \\
\hline 3.25 & CORO2A & Coronin, actin binding protein, $2 \mathrm{~A}$ \\
\hline 3.23 & GCHFR & GTP cyclohydrolase I feedback regulator \\
\hline 3.23 & ZNF436-AS1 & ZNF436 antisense RNA 1 \\
\hline 3.21 & KRT6A & Keratin 6A, type II \\
\hline 3.20 & S100P & S100 calcium binding protein $\mathrm{P}$ \\
\hline 3.18 & VAT1 & Vesicle amine transport 1 \\
\hline 3.16 & RARRES3 & Retinoic acid receptor responder (tazarotene induced) 3 \\
\hline 3.16 & GALNT12 & Polypeptide N-acetylgalactosaminyltransferase 12 \\
\hline 3.16 & $L A M P 3$ & Lysosomal-associated membrane protein 3 \\
\hline 3.09 & IRF7 & Interferon regulatory factor 7 \\
\hline 3.06 & PRR15 & Proline rich 15 \\
\hline 3.01 & SLFN5 & Schlafen family member 5 \\
\hline 2.97 & Clorf116 & Chromosome 1 open reading frame 116 \\
\hline 2.96 & PTPRM & Protein tyrosine phosphatase, receptor type, $\mathrm{M}$ \\
\hline 2.96 & $A B C G 1$ & ATP binding cassette subfamily $\mathrm{G}$ member 1 \\
\hline 2.95 & $S Q R D L$ & Sulfide quinone reductase-like (yeast) \\
\hline 2.93 & ADAM8 & ADAM metallopeptidase domain 8 \\
\hline 2.92 & $S H 3 K B P 1$ & SH3-domain kinase binding protein 1 \\
\hline 2.92 & $R S A D 2$ & Radical S-adenosyl methionine domain containing 2 \\
\hline 2.91 & $K H D C 1 L$ & KH homology domain containing 1-like \\
\hline 2.91 & $W F D C 2$ & WAP four-disulfide core domain 2 \\
\hline 2.90 & $P L A 2 G 4 A$ & Phospholipase A2, group IVA (cytosolic, calcium-dependent) \\
\hline 2.87 & SYNE3 & Long intergenic non-protein coding RNA 341 \\
\hline 2.85 & STC1 & Stanniocalcin 1 \\
\hline 2.85 & $G A L C$ & Galactosylceramidase \\
\hline 2.83 & $N O V$ & Nephroblastoma overexpressed \\
\hline 2.82 & $C P E B 4$ & Cytoplasmic polyadenylation element binding protein 4 \\
\hline
\end{tabular}


Table I. Continued.

B, Downregulated genes

\begin{tabular}{|c|c|c|}
\hline $\mathrm{FC}$ & Gene symbol & Description \\
\hline-17.74 & ZNF664 & Zinc finger protein 664 \\
\hline-11.35 & COTL1 & Coactosin-like F-actin binding protein 1 \\
\hline-9.95 & $D D B 1$ & Damage-specific DNA binding protein 1 \\
\hline-9.31 & $P L K 2$ & Polo-like kinase 2 \\
\hline-8.11 & $D H F R$ & Dihydrofolate reductase \\
\hline-7.32 & $F K B P 9$ & FK506 binding protein 9 \\
\hline-6.83 & $C T G F$ & Connective tissue growth factor \\
\hline-6.72 & $D Y N L L 2$ & Dynein, light chain, LC8-type 2 \\
\hline-6.43 & $E I F 4 H$ & Eukaryotic translation initiation factor $4 \mathrm{H}$ \\
\hline-6.24 & $C B X 5$ & Chromobox homolog 5 \\
\hline-6.14 & EMP1 & Epithelial membrane protein 1 \\
\hline-6.10 & $F C F 1$ & FCF1 rRNA-processing protein \\
\hline-6.07 & TMPO & Thymopoietin \\
\hline-6.01 & CHP1 & Calcineurin-like EF-hand protein 1 \\
\hline-5.99 & TOR1AIP2 & Torsin A interacting protein 2 \\
\hline-5.94 & $S A F B$ & Scaffold attachment factor B \\
\hline-5.92 & ACTN4 & Actinin, $\alpha 4$ \\
\hline-5.80 & OS9 & Osteosarcoma amplified 9, endoplasmic reticulum lectin \\
\hline-5.76 & SART1 & Squamous cell carcinoma antigen recognized by T-cells 1 \\
\hline-5.69 & HNRNPAl & Heterogeneous nuclear ribonucleoprotein A1 \\
\hline-5.68 & IST1 & Increased sodium tolerance 1 homolog (yeast) \\
\hline-5.52 & SF3B3 & Splicing factor $3 \mathrm{~b}$ subunit 3 \\
\hline-5.50 & $C Y B 5 R 3$ & Cytochrome b5 reductase 3 \\
\hline-5.40 & PIM1 & Pim-1 proto-oncogene, serine/threonine kinase \\
\hline-5.36 & $Y Y 1 A P 1$ & YY1 associated protein 1 \\
\hline-5.31 & HSPA5 & Heat shock 70kDa protein 5 (glucose-regulated protein, $78 \mathrm{kDa}$ ) \\
\hline-5.27 & CNN2 & Calponin 2 \\
\hline-5.23 & FER & fer (fps/fes related) tyrosine kinase \\
\hline-5.20 & MRPS27 & Mitochondrial ribosomal protein S27 \\
\hline-5.08 & $A R F G A P 2$ & ADP-ribosylation factor GTPase activating protein 2 \\
\hline-5.05 & $L A M P 1$ & Lysosomal-associated membrane protein 1 \\
\hline-5.05 & $R E L A$ & v-rel avian reticuloendotheliosis viral oncogene homolog A \\
\hline-5.01 & KRT5 & Keratin 5, type II \\
\hline-4.90 & $Q K I$ & QKI, KH domain containing, RNA binding \\
\hline-4.84 & STIP1 & Stress-induced phosphoprotein 1 \\
\hline-4.82 & $A P 1 G 1$ & Adaptor-related protein complex $1, \gamma 1$ subunit \\
\hline-4.74 & $M C M 7$ & minichromosome maintenance complex component 7 \\
\hline-4.68 & $A K T 3$ & v-akt murine thymoma viral oncogene homolog 3 \\
\hline-4.63 & $C T T N$ & Cortactin \\
\hline-4.6 & $F A M 98 B$ & Family with sequence similarity 98 , member B \\
\hline-4.57 & $\mathrm{ZDHHC7}$ & Zinc finger, DHHC-type containing 7 \\
\hline-4.45 & $E E F 2$ & Eukaryotic translation elongation factor 2 \\
\hline-4.45 & $H M G A 1$ & High mobility group AT-hook 1 \\
\hline-4.41 & $C O P B 2$ & Coatomer protein complex subunit $\beta 2$ ( $\beta$ prime $)$ \\
\hline-4.4 & МYH9 & Myosin, heavy chain 9 , non-muscle \\
\hline-4.39 & MCM4 & Minichromosome maintenance complex component 4 \\
\hline-4.39 & POLDIP3 & Polymerase (DNA-directed), delta interacting protein 3 \\
\hline-4.37 & $R A B 1 A / 1 B$ & RAB1A, RAB1B, members RAS oncogene family \\
\hline-4.32 & CNOT1 & CCR4-NOT transcription complex subunit 1 \\
\hline
\end{tabular}

FC, fold change. 
Table II. Major pathways concerned in FaDu cells, triggered by treatment with $10 \mu \mathrm{g} / \mathrm{ml}$ NSC-631570 for $48 \mathrm{~h}$.

\begin{tabular}{|c|c|c|}
\hline Pathway/FC & Gene symbol & Description \\
\hline \multicolumn{3}{|l|}{ Apoptosis } \\
\hline 3.09 & IRF7 & Interferon regulatory factor 7 \\
\hline 2.53 & IRF5 & Interferon regulatory factor 5 \\
\hline-2.10 & $I K B K B$ & Inhibitor of kappa light polypeptide gene enhancer in B-cells, kinase $\beta$ \\
\hline-5.05 & RELA & v-rel avian reticuloendotheliosis viral oncogene homolog A \\
\hline-2.18 & $B A K 1$ & BCL2-antagonist/killer 1 \\
\hline-3.69 & CASP2 & Caspase 2 \\
\hline-2.78 & CASP8 & Caspase 8 , apoptosis-related cysteine peptidase \\
\hline-2.34 & $B C L 2 L 1$ & BCL2-like 1 \\
\hline-2.56 & TP53 & Tumor protein p53 \\
\hline-3.49 & MCL1 & Myeloid cell leukemia 1 \\
\hline-2.47 & $B C L 2 L 2$ & BCL2-like 2 \\
\hline \multicolumn{3}{|l|}{ Cell cycle } \\
\hline-2.17 & $\mathrm{CDH1}$ & Cadherin 1 , type 1 \\
\hline-2.18 & $C D C 14 B$ & Cell division cycle 14B \\
\hline 2.35 & $T B C 1 D 8$ & TBC1 domain family, member 8 (with GRAM domain) \\
\hline-2.53 & $H D A C l$ & Histone deacetylase 1 \\
\hline-2.09 & $C D C 20$ & Cell division cycle 20 \\
\hline-2.67 & $P R K D C$ & Protein kinase, DNA-activated, catalytic polypeptide \\
\hline-2.09 & $H D A C 8$ & Histone deacetylase 8 \\
\hline-3.47 & PLK1 & Polo-like kinase 1 \\
\hline-3.36 & $S K P 2$ & S-phase kinase-associated protein 2, E3 ubiquitin protein ligase \\
\hline-4.39 & MCM4 & Minichromosome maintenance complex component 4 \\
\hline-2.62 & MCM6 & Minichromosome maintenance complex component 6 \\
\hline-4.74 & $M C M 7$ & Minichromosome maintenance complex component 7 \\
\hline-2.89 & $E 2 F 4$ & E2F transcription factor 4, p107/p130-binding \\
\hline 2.63 & CCNE1 & Cyclin E1 \\
\hline-3.49 & CCND2 & Cyclin D2 \\
\hline \multicolumn{3}{|c|}{ Integrin-mediated cell adhesion } \\
\hline-2.28 & $P D P K 1$ & 3-phosphoinositide dependent protein kinase 1 \\
\hline-3.09 & $C R K$ & v-crk avian sarcoma virus CT10 oncogene homolog \\
\hline-2.02 & SHCl & SHC (Src homology 2 domain containing) transforming protein 1 \\
\hline 2.17 & SEPP1 & selenoprotein P, plasma, 1 \\
\hline 2.29 & $I T G A 2$ & Integrin, $\alpha 2$ (CD49B, $\alpha 2$ subunit of VLA-2 receptor) \\
\hline-2.77 & CAPN1 & Calpain $1,(\mathrm{mu} / \mathrm{I})$ large subunit \\
\hline-3.52 & $P X N$ & Paxillin \\
\hline-2.73 & $P D P K 1$ & 3-Phosphoinositide dependent protein kinase 1 \\
\hline-4.68 & AKT3 & v-akt murine thymoma viral oncogene homolog 3 \\
\hline \multicolumn{3}{|c|}{ mRNA processing } \\
\hline-2.05 & RPS 28 & Ribosomal protein S28 \\
\hline-2.12 & DHX16 & DEAH (Asp-Glu-Ala-His) box polypeptide 16 \\
\hline-2.83 & CPSF4 & Cleavage and polyadenylation specific factor 4 \\
\hline-3.77 & RNPS1 & RNA binding protein $\mathrm{S} 1$, serine-rich domain \\
\hline-3.13 & SRRMI & Serine/arginine repetitive matrix 1 \\
\hline-2.02 & SFSWAP & Splicing factor, suppressor of white-apricot family \\
\hline-3.14 & $S U G P 1$ & SURP and G-patch domain containing 1 \\
\hline-2.40 & RNPS1 & RNA binding protein $\mathrm{S} 1$, serine-rich domain \\
\hline-2.07 & $N C B P 2$ & Nuclear cap binding protein subunit 2 \\
\hline-3.85 & $N X F 1$ & Nuclear RNA export factor 1 \\
\hline-2.72 & $H N R N P L$ & Heterogeneous nuclear ribonucleoprotein L \\
\hline-2.88 & $H N R N P U$ & Heterogeneous nuclear ribonucleoprotein $\mathrm{U}$ \\
\hline-2.45 & $T A F 13$ & TAF13 RNA polymerase II \\
\hline
\end{tabular}


Table II. Continued.

\begin{tabular}{lll}
\hline Pathway/FC & Gene symbol & \\
\hline-2.82 & POLRIA & Polymerase (RNA) I polypeptide A \\
-2.79 & GTF2E1 & General transcription factor IIE subunit 1 \\
-2.71 & $P O L R 2 E$ & Polymerase (RNA) II (DNA directed) polypeptide E, 25 kDa \\
-2.76 & $E R C C 2$ & Excision repair cross-complementation group 2 \\
Translation factors & & \\
-4.45 & $E E F 2$ & Eukaryotic translation elongation factor 2 \\
-3.58 & $E I F 2 S 3$ & Eukaryotic translation initiation factor 2, subunit 3 $\gamma, 52 \mathrm{kDa}$ \\
-2.65 & $E I F 3 F$ & Eukaryotic translation initiation factor 3, subunit F \\
-6.43 & $E I F 4 H$ & Eukaryotic translation initiation factor 4H \\
-4.44 & $E E F 2$ & Eukaryotic translation elongation factor 2 \\
-2.75 & $E I F 4 B$ & Eukaryotic translation initiation factor 4B \\
-2.57 & $E I F 5 A / 5 A L 1$ & Eukaryotic translation initiation factor 5A; 5A-like 1 \\
-2.24 & $E I F 2 A K 1$ & Eukaryotic translation initiation factor 2- $\alpha$ kinase 1 \\
-2.10 & $E I F 4 A 2$ & Eukaryotic translation initiation factor 4A2 \\
\hline
\end{tabular}

Genes were clustered using the Affymetrix tool TAC4.0. FC, fold change.
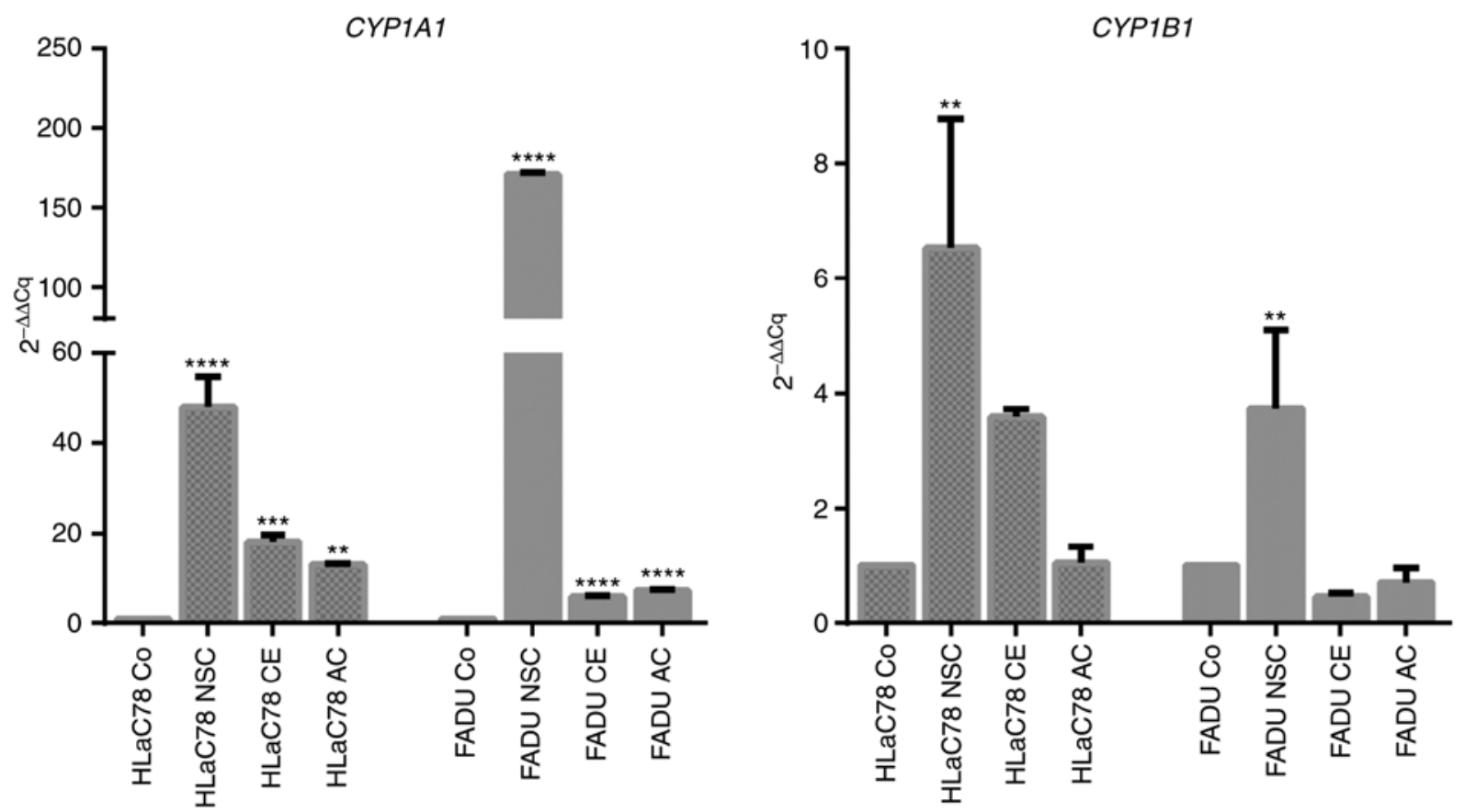

Figure 6. TaqMan RT-PCR analysis of NSC-631570 (NSC), chelerythrine (CE) and allocryptopine (AC)-treated FaDu and HLaC78 cells. Gene expression was measured followed $48 \mathrm{~h}$ incubation of the cell lines with $\mathrm{EC}_{50}$ concentrations of each substance/extract. Values are presented as mean \pm standard deviation. ${ }_{* * * * *} \mathrm{P}<0.0001,{ }^{* * *} \mathrm{P}<0.001,{ }^{* *} \mathrm{P}<0.01$; statistically significant values; ANOVA Dunnett's multiple comparison test, compared to the control. Co, untreated control cells.

of xenografted tumors in vivo without considerable toxic side effects (29), shed new light on the potential use of chelerythrine as an anticancer therapeutic agent.

HNSCC cell death induced by allocryptopine required concentrations up to $1 \mathrm{mM}$, excluding this alkaloid from further studies. Certain changes in gene expression, however (e.g. upregulation of CYP1A1), triggered by NSC-631570, may be caused or at least supported by the action of allocryptopine. The upregulation of cytochrome $\mathrm{P} 4501 \mathrm{~A}$ in response to allocryptopine and protopine has been shown in human hepatocytes and hepatic cancer cells (29).

Cell migration, one of the hallmarks of metastasis, is crucial for tumor formation and progression towards metastatic phenotypes. Especially in HNSCC, this process can be life-threatening, as surgical removal of locally invaded tumor cells in surrounding tissue is difficult without severe functional impairment. To evaluate the influence of NSC-631570 on the invasion on gelatine, laminin, fibronectin, collagen type I and 

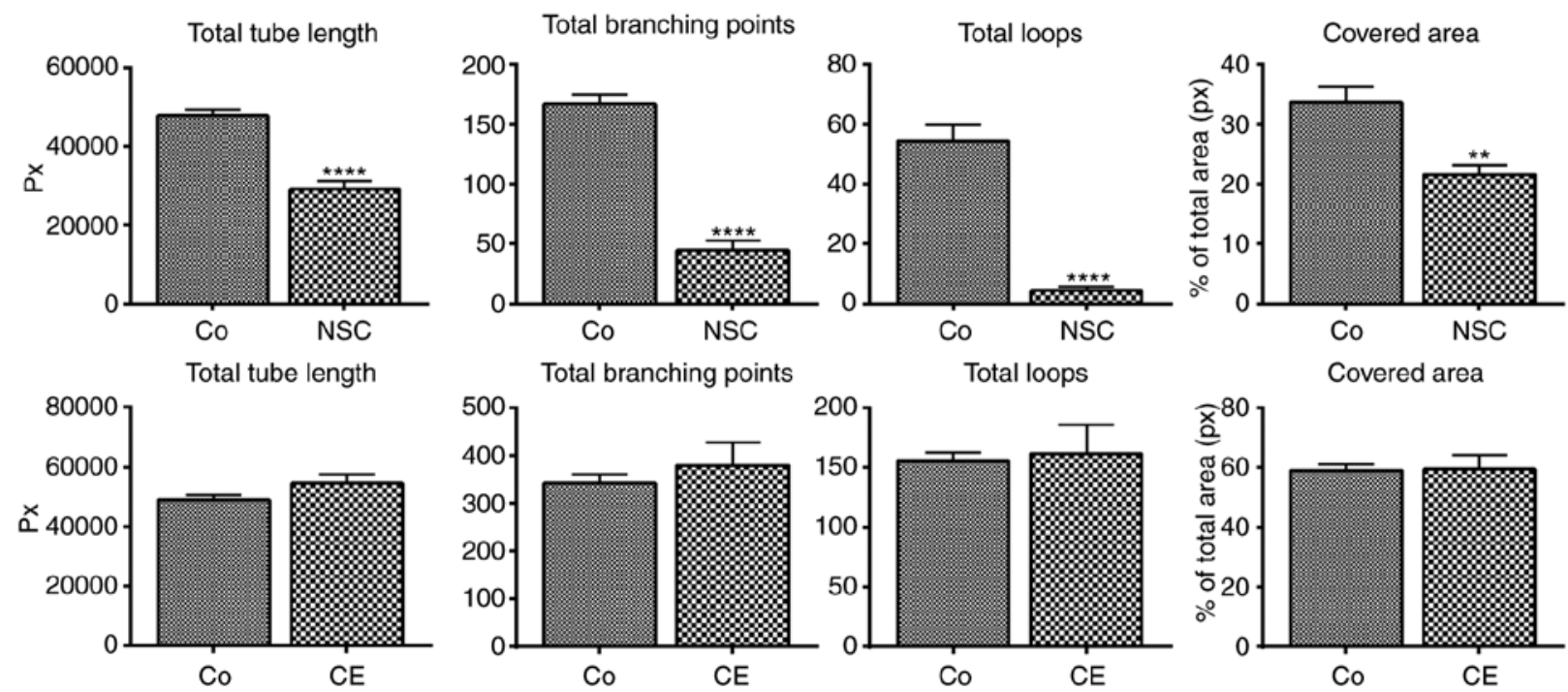

Figure 7. Anti-angiogenic action of NSC-631570 (NSC) and chelerythrine (CE) was tested using a tube formation assay. HUVECs were incubated for 6 h with or without NSC- 631570 or chelerythrine at $\mathrm{EC}_{50}$ concentrations. Image analysis showed a significant decrease in total tube length, total branching points, total loops and covered area (\%) by NSC-631570 treatment compared to untreated HUVEC tube formation control (Co). In contrast, chelerythrine was not able to decrease any of the parameters significantly. Data are displayed as the mean of five tube formation assays \pm standard deviation ${ }^{* * * * *} \mathrm{P}<0.0001,{ }^{* * *} \mathrm{P}<0.01$, statistically significant values (unpaired t-test) compared to the control. HUVECs, human umbilical vein endothelial cells.

Matrigel, a spheroid-based invasion assay was performed. $\mathrm{FaDu}$ and HLaC78 spheroids were treated with or without the $\mathrm{EC}_{50}$ of NSC-631570 for $24 \mathrm{~h}$. Invasion of FaDu cells was significantly inhibited on all tested ECM substrates. For the highly invasive cell line HLaC78, significance was not reached for the invasion inhibition on laminin.

Chelerythrine failed to inhibit invasion in our invasion model, although it has been published to have anti-metastatic properties in hepatocellular carcinoma cell lines (30).

Tube formation assays using HUVECs, cultivated with or without NSC-631570, revealed a significant inhibition of angiogenesis, which was previously presented at a congress in Brazil in 1998 (31) by Wassil Nowicky, the manufacturer of NSC-631570. The role of chelerythrine in angiogenesis inhibition has not been analyzed to date, although it has been shown that it was able to downregulate the expression of vascular endothelial growth factor A (VEGF-A) in MCF-7 breast cancer cells. In the present study, chelerythrine clearly failed to inhibit angiogenesis. However, it has to be taken into consideration, that the tube formation assay solely comprises inhibition of endothelial cell tube formation. It does not comprise tumor cell-derived angiogenic signals.

The high impact of NSC-631570 was found to be accompanied by gene expression changes. Microarray analysis showed differential expression of 1,195 genes caused by NSC-631570, whereby 268 genes were upregulated and 927 were downregulated. The most striking changes in gene expression revealed by microarray analysis occurred in the genes $C Y P 1 A 1$ and $C Y P 1 B 1$, which were strongly upregulated. $C Y P 1 A 1$ and $C Y P 1 B 1$ are involved in the xenobiotic metabolism of poly-aromatic carcinogens and steroid hormones (among others), as well as anticancer drugs. Therefore, they have been associated with drug resistance in cancers (32). Microarray data captured for $C Y P 1 A 1$ and $C Y P 1 B 1$ were verified by RT-PCR for FaDu and HLaC78 cells, treated either with NSC-631570, chelerythrine or allocryptopine alone.
The upregulation of $C Y P 1 A 1$ and $C Y P 1 B 1$ occurred in both cell lines, indicating that this effect is not specific for the FaDu cell line and may be a general effect in HNSCC cells. Chelerythrine and allocryptopine seem to contribute to the upregulation of $C Y P 1 A 1$, while $C Y P 1 B 1$ expression was not influenced significantly by both active ingredients. These results are not in agreement with previous studies of El-Readi et al (22). They observed a downregulation of $C Y P 1 A 1$ and $C Y P 1 B 1$ following treatment with a $C$. majus extract, concluding that the tested colon cancer cells overcame drug resistance upon treatment. The role of the mainly extrahepatic occurring CYP1 family, which belongs to the cytochrome P450 system, and especially that of CYP1A1, is controversially discussed. $C Y P 1 A 1$ has been shown to be involved in carcinogenesis by activating pro-carcinogens, such as $\mathrm{N}$-nitrosamines. On the other hand it has been shown to be cancer-preventive by metabolizing and thus activating dietary compounds, such as flavonoids (reviewed in ref 33). Possibly, a certain homeostasis of the diverse functions of that enzyme determines its role in cancer. The observed upregulation of CYP1Al in response to treatment with NSC-631570 or the isolated celandine alkaloids chelerythrine and allocryptopine in HNSCC cell lines therefore cannot be assigned to the cytotoxicity of the drug or to a progression in drug resistance. Interestingly, similar results were published by Orland et al (34). The authors likewise reported an upregulation of CYP1 family genes in HepG2 liver cancer cell lines, caused by a Chelidonium majus extract.

In summary, NSC-631570 showed a high anticancer impact in HNSCC cell lines. The extract exhibited cytotoxic, anti-invasive and pro-apoptotic activities on HNSCC cell lines. Furthermore, it acted in an anti-angiogenic manner on endothelial cells. Compared to its major ingredient chelerythrine, it showed clear advantages concerning the aqueous formulation, the toxicity on primary cells and anti-migratory properties. 


\section{Acknowledgements}

We would like to thank Dr Wassil Nowicky for providing NSC-631570.

\section{Funding}

This research received no specific grant from any funding agency in the public, commercial, or not-for-profit sectors.

\section{Availability of data and materials}

The datasets used and/or analyzed during the current study are available from the corresponding author on reasonable request.

\section{Authors' contributions}

$\mathrm{RH}$ performed all cell culture experiments, apoptosis and RT-qPCR. JS performed LC-MS analysis. JR assisted in molecular biological experiments. CP was responsible for cell culture maintenance and tube formation assays. UH provided material and equipment for LC-MS analysis. MS collected the data and evaluated the results and assisted in writing the manuscript. All authors read and approved the manuscript and agree to be accountable for all aspects of the research in ensuring that the accuracy or integrity of any part of the work are appropriately investigated and resolved.

\section{Ethics approval and consent to participate}

Mucosal keratinocytes and fibroblasts were obtained from tonsil surgery. Informed written consent was obtained prior to enrolment in the study. The study was approved by the Institutional Ethics Committee on Human Research of the Julius Maximilian University Würzburg (study approval no. 16/06).

\section{Patient consent for publication}

Not applicable.

\section{Competing interests}

The authors declare that they have no competing interests. There is no other active or previous relation or collaboration with Dr W. Nowicky, who generously provided NSC-631570.

\section{References}

1. Kamangar F, Dores GM and Anderson WF: Patterns of cancer incidence, mortality, and prevalence across five continents: Defining priorities to reduce cancer disparities in different geographic regions of the world. J Clin Oncol 24: 2137-2150, 2006

2. Goerner M, Seiwert TY and Sudhoff H: Molecular targeted therapies in head and neck cancer-an update of recent developments. Head Neck Oncol 2: 8, 2010.

3. Hartwell JL: Plants Used Against Cancer: A Survey. Bioactive Plants Vol II. Quarterman Publications, Lawrence, MA, 1982.

4. Danilos J, Zbroja-Sontag W, Baran E, Kurylcio L, Kondratowicz L and Jusiak L: Preliminary studies on the effect of Ukrain (Tris(2-([5bS-(5ba,6b,12ba)]-5b,6,7,12b,13,14-hexah ydro-13-methyl[1,3] benzodioxolo[5,6-v]-1-3-dioxolo[4,5-i]phenanthridinium-6-ol]-ethaneaminyl)phosphinesulfide. $6 \mathrm{HCl}$ ) on the immunological response in patients with malignant tumours. Drugs Exp Clin Res 18 (Suppl): S55-S62, 1992.
5. Hohenwarter O, Strutzenberger K, Katinger H, Liepins A and Nowicky JW: Selective inhibition of in vitro cell growth by the anti-tumour drug Ukrain. Drugs Exp Clin Res 18 (Suppl): S1-S4, 1992.

6. Sotomayor EM, Rao K, Lopez DM and Liepins A: Enhancement of macrophage tumouricidal activity by the alkaloid derivative Ukrain. In vitro and in vivo studies. Drugs Exp Clin Res 18 (Suppl): S5-S11, 1992.

7. Kadan P, Korsh OB and Hiesmayr W: Ukrain in the treatment of urethral recurrent carcinoma (case report). Drugs Exp Clin Res 22: 271-273, 1996

8. Lohninger A, Korsh OB and Melnyk A: Combined therapy with Ukrain and chemotherapy in ovarian cancer (case report). Drugs Exp Clin Res 22: 259-262, 1996.

9. Schramm E, Nowicky JW and Godysh Y: Biophysiological effects of Ukrain therapy in a patient with breast cancer (case report). Drugs Exp Clin Res 22: 247-254, 1996.

10. Habermehl D, Kammerer B, Handrick R, Eldh T, Gruber C, Cordes N, Daniel PT, Plasswilm L, Bamberg M, Belka C and Jendrossek V: Proapoptotic activity of Ukrain is based on Chelidonium majus L. alkaloids and mediated via a mitochondrial death pathway. BMC Cancer 6: 14, 2006.

11. Lanvers-Kaminsky C, Nolting DM, Köster J, Schröder A, Sandkötter J and Boos J: In-vitro toxicity of Ukrain against human Ewing tumor cell lines. Anticancer Drugs 17: 1025-1030, 2006.

12. Panzer A, Hamel E, Joubert AM, Bianchi PC and Seegers JC: Ukrain(TM), a semisynthetic Chelidonium majus alkaloid derivative, acts by inhibition of tubulin polymerization in normal and malignant cell lines. Cancer Lett 160: 149-157, 2000.

13. Panzer A, Joubert AM, Bianchi PC and Seegers JC: The antimitotic effects of Ukrain, a Chelidonium majus alkaloid derivative, are reversible in vitro. Cancer Lett 150: 85-92, 2000.

14. Gagliano N, Moscheni C, Torri C, Donetti E, Magnani I, Costa F, Nowicky W and Gioia M: Ukrain modulates glial fibrillary acidic protein, but not connexin 43 expression, and induces apoptosis in human cultured glioblastoma cells. Anticancer Drugs 18: 669-676, 2007.

15. Herrmann R, Roller J, Polednik C and Schmidt M: Effect of chelidonine on growth, invasion, angiogenesis and gene expression in head and neck cancer cell lines. Oncol Lett 16: 3108-3116, 2018.

16. Zenner HP, Lehner W and Herrmann IF: Establishment of carcinoma cell lines from larynx and submandibular gland. Arch Otorhinolaryngol 225: 269-277, 1979.

17. Schmidt M, Grünsfelder P and Hoppe F: Induction of matrix metalloproteinases in keratinocytes by cholesteatoma debris and granulation tissue extracts. Eur Arch Otorhinolaryngol 257: 425-429, 2000

18. Vermes I, Haanen C, Steffens-Nakken H and Reutelingsperger C: A novel assay for apoptosis. Flow cytometric detection of phosphatidylserine expression on early apoptotic cells using fluorescein labelled Annexin V. J Immunol Methods 184: 39-51, 1995.

19. Irizarry RA, Hobbs B, Collin F, Beazer-Barclay YD, Antonellis KJ, Scherf U and Speed TP: Exploration, normalization, and summaries of high density oligonucleotide array probe level data. Biostatistics 4: 249-264, 2003.

20. Bolstad BM, Irizarry RA, Astrand M and Speed TP: A comparison of normalization methods for high density oligonucleotide array data based on variance and bias. Bioinformatics 19: 185-193, 2003.

21. Livak KJ and Schmittgen TD: Analysis of relative gene expression data using real-time quantitative PCR and the 2(-Delta Delta C(T)) method. Methods 25: 402-408, 2001.

22. El-Readi MZ, Eid S, Ashour ML, Tahrani A and Wink M: Modulation of multidrug resistance in cancer cells by chelidonine and Chelidonium majus alkaloids. Phytomedicine 20: 282-294, 2013.

23. Jesionek W, Fornal E, Majer-Dziedzic B, Móricz AM, Nowicky W and Choma IM: Investigation of the composition and antibacterial activity of Ukrain $^{\mathrm{TM}}$ drug using liquid chromatography techniques. J Chromatogr A 1429: 340-347, 2016.

24. Kulp M and Bragina O: Capillary electrophoretic study of the synergistic biological effects of alkaloids from Chelidonium majus L. in normal and cancer cells. Anal Bioanal Chem 405: 3391-3397, 2013.

25. Malíková J, Zdarilová A, Hlobilková A and Ulrichová J: The effect of chelerythrine on cell growth, apoptosis, and cell cycle in human normal and cancer cells in comparison with sanguinarine. Cell Biol Toxicol 22: 439-453, 2006. 
26. Mochly-Rosen D, Das K and Grimes KV: Protein kinase C, an elusive therapeutic target? Nat Rev Drug Discov 11: 937-957, 2012.

27. Jana J, Mondal S, Bhattacharjee P, Sengupta P, Roychowdhury T, Saha P, Kundu P and Chatterjee S: Chelerythrine downregulates expression of VEGFA, BCL2 and KRAS by arresting G-Quadruplex structures at their promoter regions. Sci Rep 7: 40706, 2017.

28. Banerjee A, Sanyal S, Dutta S, Chakraborty P, Das PP, Jana K, Vasudevan M, Das C and Dasgupta D: The plant alkaloid chelerythrine binds to chromatin, alters H3K9Ac and modulates global gene expression. J Biomol Struct Dyn 35: 1491-1499, 2017.

29. Chmura SJ, Dolan ME, Cha A, Mauceri HJ, Kufe DW and Weichselbaum RR: In vitro and in vivo activity of protein kinase $\mathrm{C}$ inhibitor chelerythrine chloride induces tumor cell toxicity and growth delay in vivo. Clin Cancer Res 6: 737-742, 2000.
30. Zhu Y, Pan Y, Zhang G, Wu Y, Zhong W, Chu C, Qian Y and Zhu G: Chelerythrine inhibits human hepatocellular carcinoma metastasis in vitro. Biol Pharm Bull 41: 36-46, 2018.

31. Koshelnick J, Moskvina E, Binder BR and Nowicky JW: Ukrain (NSC-631570) inhibits angiogenic differentiation of human endothelial cells in vitro. In: 17th International Cancer Congress, Brazil; pp91-95, 1998.

32. Rodriguez M and Potter DA: CYP1A1 regulates breast cancer proliferation and survival. Mol Cancer Res 11: 780-792, 2013.

33. Androutsopoulos VP, Tsatsakis AM and Spandidos DA Cytochrome P450 CYP1A1: Wider roles in cancer progression and prevention. BMC Cancer 9: 187, 2009.

34. Orland A, Knapp K, König GM, Ulrich-Merzenich G and Knöß W: Combining metabolomic analysis and microarray gene expression analysis in the characterization of the medicinal plant Chelidonium majus L. Phytomedicine 21: 1587-1596, 2014. 